IZA DP No. 5385

Labor Market Effects of Trade and FDI:

Recent Advances and Research Gaps

Michael Pflüger

Uwe Blien

Joachim Möller

Michael Moritz

December 2010 


\title{
Labor Market Effects of Trade and FDI: Recent Advances and Research Gaps
}

\author{
Michael Pflüger \\ University of Passau, \\ DIW Berlin and IZA \\ Uwe Blien \\ University of Bamberg, \\ IAB Nürnberg and IZA \\ Joachim Möller \\ University of Regensburg, \\ IAB Nürnberg and IZA \\ Michael Moritz \\ IAB Nürnberg
}

Discussion Paper No. 5385
December 2010

IZA

P.O. Box 7240

53072 Bonn

Germany

Phone: +49-228-3894-0

Fax: +49-228-3894-180

E-mail: iza@iza.org

Any opinions expressed here are those of the author(s) and not those of IZA. Research published in this series may include views on policy, but the institute itself takes no institutional policy positions.

The Institute for the Study of Labor (IZA) in Bonn is a local and virtual international research center and a place of communication between science, politics and business. IZA is an independent nonprofit organization supported by Deutsche Post Foundation. The center is associated with the University of Bonn and offers a stimulating research environment through its international network, workshops and conferences, data service, project support, research visits and doctoral program. IZA engages in (i) original and internationally competitive research in all fields of labor economics, (ii) development of policy concepts, and (iii) dissemination of research results and concepts to the interested public.

IZA Discussion Papers often represent preliminary work and are circulated to encourage discussion. Citation of such a paper should account for its provisional character. A revised version may be available directly from the author. 
IZA Discussion Paper No. 5385

December 2010

\section{ABSTRACT}

\section{Labor Market Effects of Trade and FDI: Recent Advances and Research Gaps}

This paper pursues three aims. First, we provide a review of current theoretical advances which pertain to the relationship between trade, FDI and labor markets. We do so under the following (not mutually exclusive) headings: (1) slicing-up the value added chain and the turn to a task-based approach, (2) firm heterogeneity and labor markets, (3) complex offshoring (integration) and sourcing strategies and (4) location of firms and labor markets. Second, we overview existing empirical work covering the labor market effects of trade and FDI. Finally, we identify and summarize the existing research gaps and thereby we highlight promising avenues for future research.

JEL Classification: F16, F23, R12, J60

Keywords: offshoring, outsourcing, FDI, trade, labor markets, agglomeration

Corresponding author:

Michael Pflüger

Faculty of Economics

University of Passau

Innstrasse 27

94032 Passau

Germany

E-mail: michael.pflueger@uni-passau.de 


\section{Introduction}

The labor market effects of trade and FDI have moved to the forefront of international research after the observation that the deterioration of the labor market position of the less skilled in the advanced countries beginning in the late 1970s - slow or even negative real wage growth of the low skilled, a rising wage differential between skilled and unskilled workers in the US and a high incidence of unemployment among the unskilled in Europe - coincided with trade liberalization episodes in transformation and newly industrializing economies (e.g. Cline 1997; Pflüger 2002; Feenstra 2010). Without neglecting the role of international trade, most analysts concluded at the end of the 1990's that the dominant force driving these developments should be seen in skilled-biased technological change. However, there were also voices (e.g. Wood 1994; Leamer 1998, 2000) that attributed a much bigger role to international trade and still others that pointed out that the competitive pressure associated with international trade stimulates technology and that technological advances in transportation and communication spur trade, thus making it problematic to disentangle the two (Acemoglu 2002). It also became clear at the end of this first wave of research that, in order to take the 'trade channel' serious, one must look beyond the simple textbook Stolper-Samuelson mechanism.

Given the strong growth of trade and FDI in recent years, the detailed examination of their labor market effects has become even more pressing (Feenstra 2010; Bhagwati and Blinder 2009; Krugman 2008; Sinn 2005). Moreover, a new phenomenon has been noticed, in particular in the U.S., the relative decline of workers in the middle of the wage distribution (Acemoglu and Autor 2010; Feenstra 2010). Importantly, there have been pathbreaking innovations in the theories of trade, location and the multinational firm which allow a fresh look at the issue.

This paper pursues three aims. First, we review current theoretical advances which pertain to the discussion about trade, FDI and labor markets. ${ }^{1}$ We do so under the following (not mutually exclusive) headings: (1) slicing-up the value added chain and the turn to a task-based approach, (2) firm heterogeneity and labor markets, (3) complex offshoring (integration) and sourcing strategies and (4) location of firms and labor markets. Second, we move on to an overview of existing empirical work covering the labor market effects of trade and FDI. Our special focus are studies pertaining to Germany. Finally, we identify and summarize the existing research gaps and thereby we highlight promising avenues for future research.

\footnotetext{
${ }^{1}$ WTO (2008) provides a survey of the theoretical developments without labor market focus, however.
} 


\section{Recent theoretical advances: trade, location and the multinational firm}

\subsection{Slicing-up the value-added chain and the turn to a task-based approach}

International trade and, even more so, foreign direct investment (FDI) have increased at historically unprecedented paces in the global economy in the last decades. Much of this is due to fast-growing expansions of trade in intermediate inputs and of trade and FDI in services (Barba Navaretti and Venables 2004; Helpman 2006; Hummels, Rappoport and Yi 1998; Hummels, Ishii and Yi 2001; Amiti and Wei 2005; Jensen and Kletzer 2005). Trade in intermediate inputs and services takes place either on markets between unaffiliated firms ('at arm's length') or within the boundaries of multinational firms. Following Sinn (2005) and Helpman (2006) we use the term international outsourcing to refer to transactions at arm's length and the terms offshoring or, synonymously, integration, to refer to deliveries by affiliated suppliers (cf. table 1). ${ }^{2}$

Underlying these developments is a phenomenon which has been termed 'slicing-up of the value added chain', 'vertical specialization', 'fragmentation of production' or the 'great unbundling' (e.g. Krugman 1995, Feenstra 1998, 2004 and Baldwin 2006) ${ }^{3}$ : the value-added process from the creation of a good or service to its final delivery to the customer is no longer performed at one location; rather, innovations in transport technology and logistics have made it possible to split this process into ever finer steps which are executed at separate locations around the globe in the most economical manner. ${ }^{4}$

Theoretical reasoning about such fragmentation processes originates in Jones and Kierzkowski (1990; see also Jones 2000) which blended traditional theories of comparative advantage with fixed-cost elements. A voluminous literature has developed since. ${ }^{5}$ Some of this literature has firmly sticked to traditional models of comparative advantage. Arguably the most prominent

\footnotetext{
${ }^{2}$ It should be noted that the terms 'outsourcing' and 'offshoring' are defined differently in the literature. Bhagwati et al. (2004) restrict the term outsourcing to services from unaffiliated companies. Grossman and Rossi-Hansberg (2006) and Buch et al. (2007) use the term offshoring to account for international transactions both with and without affiliated suppliers whereas Amiti and Wei (2005) use the label outsourcing for international transactions both within and without affiliated suppliers.

${ }^{3}$ Feenstra $(1998,2004)$ provides a yet expanded list of terms.

${ }^{4}$ Whereas the earliest examples for such fragmentation processes were confined to manufacturing activities (e.g. the car industry, see WTO 1998), the phenomenon has spread to many services which became tradeable, e.g. customer service calls (Friedman 2004), developing software (Thurm 2004) or preparing tax forms (Robertson et al. 2005). Blinder (2006) has termed this development the 'third industrial revolution'. An example which pertains to direct investment of a German firm in the area of the Czech Republic is the relocation of the Siemens accounting department to Prague (Handelsblatt 2005, September 19).

${ }^{5}$ See e.g. Arndt and Kierzkowski 2001, Deardorf (2001a, 2001b), Egger and Falkinger (2003) and Kohler (2004a, 2004b). Kohler $(2007,2008)$ provides very lucid analyses of this literature. Schott (2008) and Krugman (2008) study the fragmentation process in non-standard Heckscher-Ohlin models where countries act in different diversification cones.
} 
example is Krugman (1995) who uses the standard Heckscher-Ohlin-model with 2 countries, 2 industries and 2 factors to analyze North-South-trade and wage and employment inequalities in the North. ${ }^{6}$ However, it became quickly apparent that a $2 \times 2 \times 2$ model has severe limitations as a tool to characterize ever finer fragmentation processes. Moreover, the Stolper-Samuelson theorem associated with this model proved to be at odds with the simultaneous rise of the skillpremium in the USA (the 'North') and in Mexico (the 'South') that was observed as outsourcing activities developed within NAFTA. ${ }^{7}$

Table 1: The standard classification of organizational modes

\begin{tabular}{|c|c|c|}
\hline $\begin{array}{c}\text { activity/task performed } \\
\text { in }\end{array}$ & domestic economy & foreign economy \\
\hline $\begin{array}{c}\text { in-house } \\
\text { (affiliated suppliers) }\end{array}$ & domestic insourcing & $\begin{array}{c}\text { offshoring / integration } \\
\text { (horizontal and vertical FDI) }\end{array}$ \\
\hline $\begin{array}{c}\text { outsourcing } \\
\text { (non-affiliated suppliers) }\end{array}$ & domestic outsourcing & $\begin{array}{c}\text { international outsourcing } \\
\text { ('arm's length trade') }\end{array}$ \\
\hline
\end{tabular}

These issues were resolved in influential work by Feenstra and Hanson (1996a; 1996b; see also Feenstra 2004, 2010). Their model is rooted in the factor proportions framework with two countries but allows for a continuum of intermediate inputs which can be ranked according to their skill intensity (skilled relative to unskilled labor). These intermediates are used in combination with physical capital to produce a single manufactured good. ${ }^{8}$ North is assumed to be skilled abundant. Hence, in the initial equilibrium the relative wage of the skilled is lower in North than in South so that North specializes on the skill-intensive range of intermediates and the South on the unskilled labor intensive intermediates. Since North is also assumed to be capital abundant, capital's return is lower in North than in South, initially. Once capital is allowed to move freely, relocation from North to South sets in. This raises the unit production

\footnotetext{
${ }^{6}$ Similarly, Bhagwati et al. (2004) use variants of the basic factor-proportions framework and even a simple onegood migration model to shed light on the international outsourcing of services.

${ }^{7}$ See Feenstra and Hanson $(1996 \mathrm{~b} ; 1997)$. An evaluation of the effects of globalization in developing countries which goes beyond this US-Mexico-example, but reinforces its main message, is provided by Goldberg and Pavcnik (2007).

${ }^{8}$ Feenstra and Hanson build on Dornbusch, Fischer and Samuelson (1980).
} 
cost of intermediates in North and lowers these costs in South. This implies that the range of intermediates that are produced in South increases. Hence, the model is able to portray international outsourcing. Moreover, it follows, in turn, that the relative wage of skilled labor increases in North and South. This is intuitive since South expands intermediates which are more skill-intensive than those it performed in the initial equilibrium whereas North loses those activities that, from its perspective, require the lowest skilled-level. Feenstra and Hanson (1996a) also point to the possibility that the real wages of the unskilled can rise in both countries through international outsourcing. ${ }^{9}$

A recent analysis by Grossman and Rossi-Hansberg (2006; 2008) modifies the standard twocountry Heckscher-Ohlin-model such that each good is produced with a continuum of lowskilled and high-skilled 'tasks'. Their analysis reinforces the possibility that even persons whose 'tasks' relocate in response to cheaper offshoring opportunities can gain in real terms. ${ }^{10}$ This is due to a productivity effect associated with this offshoring which raises real wages and which may dominate traditional effects such as the Stolper-Samuelson effect. Intuitively, the effect of improvements in outsourcing technologies is similar to factor-augmenting technical progress. ${ }^{11}$ A main innovation of this model is that it highlights the structure of offshoring costs as crucial determinant for the offshoring of high- and/or low-skilled activities (Feenstra 2010). Using their model, Grossman and Rossi-Hansberg perform back-of-the envelop calculations which suggest that such a productivity effect may be at work in the United States. However, more detailed empirical work on this productivity effect is clearly called for as is more evidence on offshoring costs. $^{12}$

Given the evidence that fragmentation processes are at least as important between developed countries as in the North-South context, Grossman and Rossi-Hansberg (2010) develop a NorthNorth fragmentation model where countries are similar except for their size. Production again requires a continuum of tasks which is now assumed to be performed by one type of labor. This assumption is integrated into a monopolistic competition model in the spirit of Dixit and Stiglitz (1977). The model is also amended by the assumption of local knowledge spillovers. The determination of the location of tasks then underlies the trade-off between the advantages of concentration due to the positive technological externality and the costs of offshoring the tasks.

\footnotetext{
${ }^{9}$ Barba Navaretti and Venables (2004) adapt the Feenstra-Hanson model into a model of the multinational firm.

${ }^{10}$ Grossman and Rossi-Hansberg (2006, 2008 and also 2009) do not distinguish between outsourcing and in-house production, i.e. they collapse offshoring and international outsourcing in their model.

${ }^{11}$ It is important to note that the wage effects depend on whether a reduction in offshoring costs is similar for all industries or whether it is confined to certain industries (Grossman and Rossi-Hansberg 2006; Kohler 2008). From the perspective of Jones' classic analysis (Jones 1965) of the effects of technical progress on wages in the standard Heckscher-Ohlin, this is quite intuitive (e.g. Pflüger 2002, 2004a).

${ }^{12}$ Crinò (2009b) and Sethupathy (2008).
} 
The model has the (testable) implication that the larger country specializes on those tasks that are most costly to offshore and that the smaller country specializes on those tasks that are cheap to offshore ('country size effect').

Recent examples of fragmentation processes suggest that outsourcing- and offshoring activities are no longer confined to 'low-skilled labor' but cut across all skill classes (cf. footnote 4). A similar observation has been made with respect to activities that can be performed by a computer (Levy and Murnane 2004). Hence, the traditional classification of labor in terms of skill classes is steadily loosing its usefulness. Recent research suggests turning to a classification based on tasks. Autor, Levy and Murnane (2003) divide tasks into five categories: those requiring expert thinking, complex communication, routine cognitive processes, routine manual labor, or nonroutine manual labor. Routine tasks (whether cognitive or manual) can be performed by the computer or offshore whilst this is not true for the other activities. Hence, again trade (slicing-up the value-added chain) and technology appear to be key elements for the developments on labor markets (Leamer 2007).

Analysts of technological change have highlighted that a 'polarization' has taken place notably in US and UK labor markets: employment and wage growth polarizes into high-wage and lowwage jobs and this happens at the expense of middle-skill jobs (Acemoglu and Autor 2010; Autor, Katz and Kearney 2006; Goos and Manning 2007). Autor, Levy and Murnane (2003) show that a model of computerization is able to explain this 'polarization hypothesis': computers complement nonroutine cognitive tasks, substitute for routine tasks and have little impact on nonroutine manual tasks. This model and the follow-up work is built around a production function setting which allows for three types of tasks or skill-classes (Autor, Levy and Murnane 2003; Autor, Katz and Kearney 2006). This line of research has already initiated a wave of empirical research. Analyzing skill requirements at the workplace Spitz-Oener (2006) finds support for the polarization hypothesis for western Germany. Dustmann, Ludsteck and Schönberg (2009) provide further support for this hypothesis for Germany and so do Goos and Manning (2007) for the U.K. and Autor and Dorn (2009) for the US. In a comprehensive study Goos, Manning and Salomon (2009) find employment polarization in 14 of 16 European OECD countries in the time period 1996 to 2007 . In contrast to this striking international evidence in favor of polarization, the study by Antonczyk, Fitzenberger and Leuschner (2009) gives a mixed picture. They conclude that although the task-based approach is able to explain changes in the skill structure of employment, it fails to explain the recent marked increase in wage inequality in Germany. The authors study is based on the 1999 survey on 'Qualification and 
Occupational Career' and on the 'Working-Population-Survey' from 2006. Although the task description in both surveys is comparable, their study sample and design differs.

The investigation of links between the polarization in labor markets and trade and FDI is still in its infancy (Feenstra 2010). The recent work by labor economists which focuses on technological developments highlights the importance of going beyond a model with a very limited number of skill levels. In contrast to the first wave of research on the nexus between 'trade, technology, wages and employment' (cf. section 1), technological change and the international fragmentation of production are often seen as interrelated phenomena, at present (e.g. Autor, Katz and Kearney 2006). The reason for that is that the advancement of (information) technology appears to have indirect labor market effects which work through the international division of labor which merit further scrutiny. On the other hand, there are structural changes towards non-tradable tasks in the service sectors of advanced economies which partly reflect changes in consumer preferences: Autor and Dorn (2009), for instance, show that in the US demand for low-paid service jobs has increased because these involve mostly non-routine manual tasks which require hand-eye coordination as well as physical presence and interpersonal activities that can neither be substituted by technology nor by relocation of production processes.

\subsection{Firm heterogeneity and labor markets}

Beginning with Bernard and Jensen (1995), an extensive empirical literature has developed which, based on micro datasets that document production and trade at the firm level, shows that only a small fraction of firms that are operating in the United States and in EU countries are engaged in international trade and that these firms are larger and more productive than firms that do not export (see e.g. Helpman 2006, Bernard, Jensen, Redding and Schott 2007; Mayer and Ottaviano 2007 and Wagner 2007). ${ }^{13}$ A further and newer finding is that those firms that do export typically export multiple products to an increasing number of countries (Bernard, Jensen, Redding and Schott 2007; Bernard, Jensen and Schott 2009).

These findings could neither be explained with standard trade theories based on comparative advantage which simply feature industries operating under constant returns to scale nor with the new trade models of Krugman (1980) and others which assume that firms have symmetrical identical technologies. In response to this, new models with imperfect competition were

\footnotetext{
${ }^{13}$ There is strong evidence which shows that causality goes from productivity to exports and not the other way around (see or example Bernard and Jensen 2004, Schank et al. 2008).
} 
developed, which feature heterogeneous firms. The most popular one, set up by Melitz (2003), builds on the Dixit-Stiglitz monopolistic competition model of Krugman. ${ }^{14}$ Melitz assumes that firms are heterogeneous with respect to their productivity and that there are fixed costs of exporting which exceed the fixed costs of serving the domestic market. Then, only those firms that are able to cover the domestic fixed cost will enter the (domestic) market and only the most productive firms will find it profitable to be additionally engaged in exports. A reduction of trade barriers implies that existing exporters realize higher profits in foreign markets and that the threshold productivity level which is necessary to become an exporter falls. This enlarged export activity and the associated stronger competition on goods markets drives up the threshold level of productivity which is necessary to profitably supply the domestic market. Hence, the least productive firms will exit the market. This exit and the employment reallocation towards the most productive firms imply a rise in the average industry productivity ('firm-selection effect').

In response to a trade liberalization of such form, the Melitz-model implies considerable churning in the product market with strong repercussions on the labor market in the form of large simultaneous flows of gross job creation and destruction. ${ }^{15}$ However, there is no net change in employment and since there is only one homogeneous factor, labor, the evolution of relative factor rewards cannot be studied within the model. A recent literature addresses these two aspects, however.

Bernard, Redding and Schott (2007) integrate heterogeneous firms into a standard model which features factor proportions and monopolistic competition (Helpman and Krugman 1985). The model implies that countries specialize on industries according to the comparative advantage associated with relative factor abundance. Moreover, there is two-way trade within industries due to increasing returns to scale and love of variety and firms self-select into exporters and non-exporters as in the Melitz-model. Trade liberalization induces reallocations within industries and it raises aggregate productivity in all industries. Since this productivity growth is strongest in the comparative advantage industry, a clear prediction concerning the distribution of earnings emerges: the relative price of the factor that is used intensively in the comparative advantage industry is bid-up. Due to productivity growth, all factors may benefit in real terms, however. This anti-Stolper-Samuelson result reinforces findings discussed in the previous paragraph.

\footnotetext{
${ }^{14}$ Other prominent models were developed by Bernard et al. (2003), Yeaple (2005) and Melitz and Ottaviano (2008). Helpman (2006) provides a brief overview.

${ }^{15}$ Rodrik (1997) has early on stressed that the enlarged options and opportunities available to firms under trade liberalization may raise the volatility of employment (and wages).
} 
The one-factor framework of Melitz (2003) is retained in another set of papers which introduce labor market frictions into the model: Davis and Harrigan (2008) combine the Melitz-model with the shirking model of Shapiro and Stiglitz (1984), Egger and Kreickemeier (2008; 2009) consider fair wages, Eckel and Egger (2009) introduce unions, wage bargaining and multinational firms and Felbermayr and Prat (2010) and Helpman and Itskhoki (2010) and Helpman, Itskhoki and Redding (2010a; 2010b) focus on search in the labor market. Even though the labor market underpinnings and, therefore, specifities of these papers are different, they have important common themes. In particular, these works imply that trade (liberalization) is associated with within-group inequalities. Since product market churning is associated with churning on the labor market, homogeneous workers fare quite differently under trade liberalization: some experience rising wages, some others falling wages, some become laid-off and still others become re-employed depending on the (productivity-related) status of the employing firm. Moreover, with imperfectly competitive labor markets, neither can employment losses be ruled out nor are aggregate welfare gains from trade assured.

Finally, the finding that exporting firms typically export multiple products to an increasing range of countries has inspired a theoretical literature which, as yet, has not put the labor market effects under scrutiny. ${ }^{16}$

\subsection{Complex offshoring (integration) and sourcing strategies}

The theory of the multinational firm makes a classic distinction between two types of FDI (e.g. Markusen 2002; cf table 1). ${ }^{17}$ Horizontal foreign direct investment (HFDI) refers to investments undertaken in order to gain product market access, i.e. to supply local markets. Vertical foreign direct investment (VFDI) is performed in order to save on production costs, typically labor costs: it is the in-house variant of the phenomenon of the 'slicing-up of the value added chain' that we already referred to.

Economic theory suggests that HFDI is positively related to foreign market size, the level of (natural and artificial) trade costs, to economies of scale at the firm-level, and the similarity of countries, whereas strong plant-level scale economies make it more economical to serve foreign markets by arm's length trade. VFDI, on the other hand, is expected to be positively related to strong factor cost differentials, and firm-level economies of scale whilst being negatively

\footnotetext{
${ }^{16}$ See Bernard, Redding and Schott (2006), Eckel and Neary (2010), Feenstra and Ma (2008) and Nocke and Yeaple (2006).

${ }^{17}$ This theory builds on Dunning's (1977, 1981) 'OLI'-framework which suggests three preconditions for FDI: an ownership advantage (knowledge capital in the form of e.g. blueprints or specific human capital), a location advantage (e.g. a large market, cheap factor prices, good infrastructure and an internalization advantage (e.g. potential problems with unaffiliated suppliers or subcontractors).
} 
affected by trade costs and by coordination and communication costs associated with a disintegration of production (e.g. Barba Navaretti and Venables 2004; Feenstra 2004). Standard references suggests that, at present, HFDI accounts for the largest share of FDI flows but that the share of VFDI is increasing (see e.g. the Barba Navaretti and Venables 2004 and Feenstra 2004). This view is challenged in the study by Alfaro and Charlton (2009) building on the most comprehensive database yet, the data of Dun and Bradstreet which include more than 650,000 multinational subsidiaries in 90 countries. They show that the amount of vertical investment is underestimated in many studies because of problems with data accuracy.

The labor market effects that can be expected from these different types of international investment are not unambiguous (e.g. Buch et al. 2007). No clear prediction emerges from HFDI: neither is it in a predictable way skewed towards the use of different factor bundles abroad than compared to home, nor is the employment effect at the level of the multinational firm clear: building up an affiliate abroad implies that foreign, not domestic labor, will be employed; however, it is quite likely that the coordination of the foreign activity requires more (domestic) headquarter labor. Clearly, the employment effect that arises in general equilibrium (in contrast to the one on the level of the multinational firm) is yet different, as it will ultimately reflect the overall workings of the labor market. VFDI, on the other hand, should have strong effects on relative factor prices since the factor demand associated with VFDI is skewed towards those factors that are relatively cheap abroad. It is quite possible, however, that domestic factors gain in real terms under VFDI as we have outlined in the two previous sections.

In practice, multinational activity often comprises both horizontal and vertical investment and such complex integration strategies are growing in importance. ${ }^{18}$ This insight gave birth to the so-called 'knowledge capital model' which began to combine the two in one common model (Markusen 2002). Clearly, the implied labor market effects are then even more difficult to predict. Moreover, with more than two countries and more than two stages of production, the distinction between horizontal and vertical FDI becomes conceptually blurred. An instructive example is 'export-platform FDI' where a multinational is headquartered in one country, manufactures its goods in a subsidiary and sells the output mainly in a third country (Ekholm et al. 2004). Yet another example is provided by Grossman, Helpman and Szeidl (2006) building on Yeaple (2003). They consider a Southern country and two symmetric Northern countries which host the headquarters of firms. Final goods are produced with a combination of intermediates and assembly and these can be produced either in the headquarter country or in

\footnotetext{
${ }^{18}$ The term complex integration strategies originates in UNCTAD (1998) according to Helpman (2006).
} 
South. Consumers are located in all countries. By assumption, South has lower production costs (wages, say). However, fixed costs have to borne if intermediates and assembly are performed away from the headquarter location. Grossman, Helpman and Szeidl allow for trade costs, firmspecific productivities as in Melitz (2003) and they also consider different fixed costs for the offshoring of the intermediates and the assembly activity. They also consider trade costs for intermediates as well as for the final goods that are delivered to the consumers which are located in all three countries. Depending on the cost and productivity parameters, the model then predicts a variety of integration strategies, ranging from no offshoring to the offshoring of both activities to South as well as intermediate cases where only one activity is performed in South.] The different integration strategies outlined that result in these examples have distinct but yet unexplored repercussions on labor markets.

Not only have the integration (offshoring) strategies of multinational corporations become more complex, but the same holds true for their sourcing strategies, i.e. the decisions which parts of the production of manufactures and services to perform in-house (with affiliates) rather than at arm's length with unaffiliated firms. The modern theory of the firm focuses on three types of contractual failures that induce firms to resort to in-house activities (e.g. Barba Navaretti and Venables 2004): a first concern is that a firm wants to protect its intangible assets, notably its technological knowledge and its reputation; agency problems are a second concern: even though firm-independent agents may have superior knowledge about local markets, they may also have different objectives from the firm which creates a costs disadvantage; third, the classic 'hold-up problem' emerges when firms make relation-specific investments for which no complete contracts exist; since a party's bargaining position is weak, when an investment whose costs have been sunk are relation-specific, this parties initial investment (say the provision of a customized input) is suboptimal.

The hold-up problem has obtained most attention recently in the influential works of Antras (2003) and Antras and Helpman (2004; 2008). ${ }^{19}$ Building on the property rights theory of Grossman and Hart (1986), these authors identify a key factor which affects a firm's sourcing strategy, the so-called contractual input intensity. This concept has some resemblance to the traditional factor intensity concept but focuses on the control of intermediate inputs instead: it measures the share of intermediate inputs under the direct control of the final good producer (e.g. headquarter services) relative to the share of intermediate inputs that have to be acquired from (affiliated or unaffiliated) suppliers. Since no (major) contractual problems are to be expected concerning the intermediate inputs under direct control, the literature abstracts from

\footnotetext{
${ }^{19}$ Helpman (2006) has an expanded list of references. See also Helpman, Marin and Verdier (2008).
} 
these. However, such problems exist if intermediates are controlled by suppliers and they differ if these suppliers are affiliated (integration solution) rather than unaffiliated (outsourcing solution). Quite intuitively, under integration, final good producers can secure a higher share of the (potential) revenue that they can generate with the suppliers than they can under outsourcing, since their outside option is stronger (even though non-cooperation of affiliated suppliers destroys some of the output in case that the bargain fails). From the perspective of the property rights approach, ex ante efficiency requires that a larger share of the revenue should be given to the party that undertakes the relatively more important investment. In the present context this implies that (after controlling for differences in organizational costs) the final goods producer should choose vertical integration for high values of the contractual input intensity and outsourcing for low values. Placing these considerations into a factor proportions framework, Antras (2003) derives the prediction that the share of a country's (say the US's) intrafirm imports should be increasing in the share of the inputs provided by its headquarters firms. Combining these considerations with heterogeneous firms as in Melitz (2003), Antras and Helpman (2004) conclude that the share of a country's intrafirm imports will be large only, when in addition to the condition spelled out in Antras (2003), the firm's productivity is high. ${ }^{20}$ These predictions obtain quite strong support in the empirical literature focusing on the United States (e.g. Nunn and Trefler 2008). The labor market implications - especially the possible impact on the wage and employment structure as well as on churning and employment volatility - of these complex sourcing strategies have not yet been put under scrutiny, however.

\subsection{Location of firms and labor markets}

The interdependencies between the location of firms and labor markets are also of great importance for our project. The development of the core-periphery model by Krugman (1991a; 1991b) which initiated the new economic geography provided a fresh look at the determinants of the location of economic activity. Krugman highlights market size effects (also referred to as market access or market potential) which arise endogenously from the interplay of increasing returns at the firm-level, trade costs and mobile demand associated with interregionally mobile labor. These market size effects - sellers appreciate large local markets because the associated demand is large and buyers appreciate large local markets because of transport costs savings - dominate the dispersion force associate with immobile consumers ('farmers') if trade costs are low enough. This model builds on Dixit and Stiglitz (1977) and on

\footnotetext{
${ }^{20}$ Antras and Helpman (2008) generalize this analysis such that inputs are partially contractible.
} 
Krugman's $(1979,1980)$ new trade contributions and is a very influential general equilibrium model with a full microfoundation (Fujita and Mori 2005).

Three strands of refinements and extensions of Krugman's model are of major for the issue of trade, FDI and labor markets. ${ }^{21}$

First, if labor is only intraregionally mobile, agglomeration can be explained by market size effects between intermediate goods producers and final goods producers (Krugman and Venables 1995; Venables 1996). If such vertical linkages exist, the entry of a multinational affiliate improves the local business conditions, thus making the entry of further firms more likely.

A second strand highlights that the space economy is also shaped by the dispersion forces associated with scarce land such as high land-rent or housing prices and urban costs such as commuting or pollution (e.g. Krugman and Livas Elizondo 1996; Helpman 1998; Tabuchi 1998; Fujita et al. 1999 and Pflüger and Tabuchi 2010).

Third, multi-region models have been developed to study the spatial allocation of economic activity between regions that differ with respect to their accessibility, e.g. internal and external regions or border regions. The framework developed in Pflüger (2004b) has been used to study the effect of the 2004 EU Eastern enlargement on the pre-enlargement periphery of the EU. This study by Brülhart et al. (2004) sets up a three region model, with two regions representing the EU's core and periphery (considered to be the regions at the Eastern borders of the 'old' EU) and the third region representing the new EU members. The study focuses on the trade opening and assumes (in line with the factual evidence up to the time of the study) that there is no labor mobility between the old and new EU members. Trade opening implies that the border regions have favored access to the customers in the East. However, border regions also face stiffer competition from the producers in the East compared to interior regions of the old EU. Brülhart et al. (2004) show that the first effect dominates the second if the share of immobile consumers in the foreign region is large enough. Quite intuitively, a large share of 'farmers' implies a large demand effect without a counteracting competition effect. Hence, under these circumstances, the model implies a relocation of industries towards border regions as a result of the enlargement. Motivated by Mexico's trade liberalization in the 1980's, Krugman and Livas Elizondo (1996) have set up another model to study the effects of external trade on the internal geography of a country (see also Fujita et al. 1999. chapt. 18). Their analysis brings urban congestion costs into the picture and shows that, starting from an initial core-periphery pattern

\footnotetext{
${ }^{21}$ Baldwin et al. (2003) and Combes et al. (2008) provide overviews of further refinements and extensions.
} 
(e.g. Mexico City versus Mexico's border regions), an external trade liberalization leads to a dispersion of economic activity, the main reason being that the relative importance of congestion costs rises in this case. Fujita et al. (1999, chapt. 18) elaborate on this analysis and show that, in a special version of the model with two increasing returns sectors and vertical linkages, particular industries may cluster, even though trade generates an overall dispersion of manufacturing activity.

Urban and regional economics have provided explanations for the agglomeration of economic activity long before the new economic geography came into existence. Krugman's innovations gave these fields new impetus, however. In fact the study of microfoundations for the agglomeration mechanisms traditionally stressed in this literature, notably the spillover of knowledge and other positive technological externalities and the advantages of pooled markets of skilled labor (human capital externalities) and other thick markets has experienced a strong revival. Glaeser (2010) and Duranton and Puga (2004) provide lucid characterizations of the microfoundations of the various mechanisms involving the sharing of assets, the matching of needs and learning.

This theoretical research also spurred a wave of empirical works that put the various agglomeration mechanisms under scrutiny. However, trying to summarize the findings succinctly, is difficult since, as two authoritative surveys put it, "there is a lot that we do not yet know about agglomeration economies" (Rosenthal and Strange 2004: 2167) and, concerning the new economic geography, "in terms of the results, (...) the dust has not yet settled" (Head and Mayer 2004: 2663). To characterize the strategies pursued and the difficulties involved it is worthwhile to consider exemplary works that are of greatest pertinence to our research project.

The study by Brülhart et al. (2004) that we already alluded to starts with a well-articulated theoretical model. In their empirical model they regress regional GDP per capita on a market potential concept, a set of dummy variables. The study corroborates a positive (though small) effect of the trade opening on the border regions' GDP per capita and a much larger effect on manufacturing employment relative to population in an alternative regression. Altogether the study thus (seems to) bring(s) out the importance of the market access effect. However, a number of problems should be acknowledged. First, the empirical model 'does not take the theory too seriously' in the parlance of Head and Mayer (2004), i.e. the market potential concept that is used is not directly derived from theory. Second, and related, even though theory tells us that the region's own market potential is of highest relevance, it is omitted from the regression 
equation to avoid simultaneity problems. Finally, the approach does not discriminate between alternative agglomeration mechanisms.

The types of problems encountered in the study by Brülhart et al. (2004) prevail in most of the literature. $^{22}$ The role of agglomeration economies for multinational's FDI decision has been looked upon for at least two decades now (see Barba Navaretti and Venables 2004, chapt. 6 for a selective survey). Since the early study by Wheeler and Mody (1992), the importance of agglomeration economies has been corroborated. However, these approaches were all inspired, but not fully grounded, in economic theory and for a long time discrimination among alternative agglomeration economies seemed to be no issue at all. An important study by Head and Mayer (2004) which examines the establishment of 452 affiliates of Japanese firms in 57 regions belonging to nine countries makes some progress in this respect. In particular, their approach is not only inspired by, but fully grounded in a new economic geography model. Head and Mayer find that a $10 \%$ increase in the market potential of a European region implies a 10,5\% increase in the probability of this region being chosen by a Japanese investor, thus corroborating the importance of market access. However, the controls that they add in the regression equation imply that intra-industry externalities (possibly knowledge spillovers) play a very strong role as well. Moreover, simultaneity and (clearcut) discrimination are yet open issues in their analysis, too. On account of the causality problem, a recent study by Redding and Sturm (2008) is the most satisfactory one, at present. They use the division of Germany after WW II as a natural experiment. The division of Germany in fact meant that for the West German border cities close to the newly erected East-German border, part of their market access was lost. Hence, from a new economic geography point of view these regions have lost their attractiveness in terms of wages and cities further away from the border are favorable locations. Redding and Sturm provide numerous controls which corroborate the decisive role of market access, and hence, the mechanism stressed in the new economic geography. Discrimination is an issue that is becoming to be addressed in a recent literature which is still in its infancy (see Redding 2009a, 2009b; and the exemplary works by Javorcik 2004, Ellison et al. 2010 and Combes et al. 2009).

\section{Evidence on the labor market effects of trade and FDI}

From an empirical point of view there is no doubt that many activities which were traditionally performed in the most advanced countries are now being outsourced or offshored to countries opening up their markets, i.e. predominantly to East Asia, Latin America and not least to

\footnotetext{
${ }^{22}$ These problems are familiar from the empirical trade literature (see Leamer and Levinsohn 1995).
} 
Central and Eastern Europe. As a final step in our review of the state of the art, we now turn the empirical literature on the labor market effects of trade and FDI.

The case of the US and Mexico. Arguably the most influential empirical works which inspired some of the most important recent theoretical advances that we already alluded to in previous paragraphs have focused on the US, Mexico and their trade relationship since the mid 1980s. In Mexico, trade liberalization led to a decentralization process away from the capital towards the regions near the U.S. border (Hanson 1998), as we already noted in sect. 2.4. Hanson's (1996, 2001) studies suggest that the expansion of export manufacturing in the Mexican border region significantly contributed to the employment growth in U.S. border manufacturing industries. Furthermore, Feenstra and Hanson $(1996 b, 1997)$ find evidence that the relative wages of highskilled workers (persons employed in the non-production sector) increased compared to those of low-skilled workers (persons employed in the production sector) not only in the United States but also in Mexico (cf. section 2.1). ${ }^{23}$ In recent years a number of works have provided evidence for the 1990s which challenge the finding of Feenstra and Hanson that international outsourcing is the driving force behind increasing wage differentials in developing countries. Chiquiar (2008) finds consistency with the Stolper-Samuelson theorem in a paper exploiting regional data and focusing on the different development of skill premiums. Though he also observes a nationwide rise in the Mexican skill premium between 1990 and 2000, he finds that unskilled wages particularly increased in regions highly integrated with the U.S. Airola and Juhn (2005) confirm the results of Feenstra and Hanson (1997) regarding the skill-upgrading in the border region containing a high proportion of maquiladoras in the $1980 \mathrm{~s}$, but find evidence that the growth in skill demand in the 1990s was much slower there compared to other Mexican regions. Since 1996 the wage bill share for more highly educated workers - a proxy for relative labor demand - has even fallen in the border region.

Evidence from further countries and regions. A quite sizable number of empirical studies has looked at the labor market effects of trade and FDI in other countries and regions. The following brief review is guided by the structure and summary offered in the recent meta-study conducted by Crinò (2009). The empirical studies focussing on Germany are discussed in a separate paragraph thereafter.

(i) According to a general finding, manufacturing outsourcing is an important determinant of rising wage inequality between skilled and unskilled during the 1980s. The result that

\footnotetext{
${ }^{23}$ The assignment of low- and high-skilled workers to the categories of production and non-production is not uncontroversial but it can be justified by the high correlation between non-production and high-skilled workers (see e.g. Geishecker 2004 on this).
} 
international outsourcing can account for a significant amount of skill upgrading in the U.S., Japan, Hong Kong and Mexico, has for example been found in the analysis of Feenstra and Hanson (2003), which is based on zero-profit conditions, an economy-wide GDP function and the estimation of the demand for skilled labor. A process of skill-upgrading in high-income countries caused by outsourcing to low-income countries is also found in e.g. Egger and Egger (2003, 2005), Feenstra and Hanson (1996b), Head and Ries (2002), Hsieh and Woo (2005), Hijzen et al. (2005) and Geishecker and Görg (2008a, 2008b). The work by Marin (Marin 2004; Lorentowicz, Marin and Raubold 2005) that we take up below provides interesting counterexamples to the mainstream view of a skill-upgrading in high-income countries, however.

(ii) Manufacturing outsourcing raises the volatility of employment although the magnitude of the effect is open to dispute. Exemplary works studying the effect are Egger et al. (2007) for Austria, Munch (2005) for Denmark and Geishecker (2008) for Germany. The latter two studies come to different conclusion: Whereas Munch finds only minor effects of outsourcing on employment volatility, Geishecker's results point to a much larger magnitude.

(iii) Service offshoring seems to have only a very small (negative) effect on the level of employment. This result comes through with particular clarity in studies for the UK (Amiti and Wei 2005, Geishecker and Görg 2008b, Görg et al. 2008) and for the U.S. (Amiti and Wei 2006, Liu and Trefler 2008). More recent work by Crinò (2007; 2009) suggests that service offshoring raises the demand for high-skilled labor in Western European countries and in the United States.

(iv) Production relocations within multinational firms seem to have had only limited effects on the labor market: although there is evidence for some substitution of domestic labor through foreign labor within multinational firms, this effect is usually found to be weak, however (see e.g. Braconier and Ekholm 2000 and Konings and Murphy 2006). Stronger effects, however, emerge in the studies by Becker et al. (2005) and Becker and Muendler (2010) that we take up below.

Studies pertaining to Germany. Given our research focus, the works pertaining to labor market effects of trade and FDI from the point of view of Germany merit particular attention. As far as German companies are concerned, it should be noted that the bulk of foreign direct investment stocks is located in the EU-15 countries (47.0\%) and in the U.S. (30.2\%). In 2004 the CEE-10 countries had a share of only $6.1 \%$ of the total foreign direct investment stocks of 
German companies (Römer 2007). ${ }^{24}$ However, the FDI growth rates in this region are tremendous, by far exceeding what has been predicted (see e.g. Lipsey 2006, Deutsche Bundesbank 2007). Between 2001 and 2006 about $60 \%$ of German companies with at least 100 employees which shifted production to foreign countries implemented their relocation activities in the new EU member states, compared to a share of $36 \%$ of relocation to China and $30 \%$ to EU-15 countries (Statistisches Bundesamt 2008). ${ }^{25}$ The increasing relevance of Central and Eastern European countries is confirmed by a survey of the German Chambers of Industry and Commerce (DIHK 2008).

An important study by Buch, Schnitzer et al. (2007) starts with the observation that research on the labor market effects of offshoring by German firms is yet scarce. The following review of these works reveals that there are yet considerable controversies.

(i) Overall employment and average wages. In his analysis of the 'bazaar economy' Germany, Sinn (2005) points out that the growth of value added of German manufacturers - as measured in terms of the growth of production - declined dramatically in the 1990s which suggests that wages and/or employment should fall. On the other hand, foreign activities strengthen the competitiveness of a multinational firm thereby creating jobs in the parent company and leading to higher wages at home. A study by Klodt and Christensen (2007) concludes that employment in firms increases significantly with an increase in their FDI. Buch, Schnitzer et al. (2007) use the survey 'Going International' carried out by the "Deutscher Industrie- und Handelskammertag (DIHK)", the 2004 wave of the IAB-Betriebspanel and the MIDI-database (Micro Database Direct Investment). Their analyses are conducted at the level of enterprises and of industries and sectors. By estimating labor demand functions they find dominating positive employment effects associated with offshoring (Buch, Schnitzer et al. 2007: 161). A comparison of sectors reveals marked differences, however. In the manufacturing sector most of the effects are negative, whereas they are positive in the service sector. The study by Temouri, and Driffield (2009) uses the commercial ORBIS data base provided by Bureau van Dijk. They show that both for the manufacturing and the service sector no negative overall employment effects emerge from the worldwide engagement of German multinationals and that the average wage effect is unclear. Becker and Muendler (2008) use propensity-score matching to identify a causal effect of increasing foreign investment. Their study is based on a linked employeremployee database. They join the Employment Statistics for 2000/2001 with data from the

\footnotetext{
${ }^{24}$ CEE-10 comprises the Central and Eastern European countries Bulgaria, Czech Republic, Estonia, Hungary, Latvia, Lithuania, Poland, Romania, Slovakia, and Slovenia.

${ }^{25}$ The percentage values do not add up to $100 \%$, since $38 \%$ of the relocating companies named more than one target country.
} 
MIDI database by using information of the commercial MARKUS database about domestic parents and affiliates of FDI-reporting firms. The fusion of the different data sources is done by a string-match procedure. Becker and Muendler find that multinational enterprises which expand abroad retain more domestic jobs than competitors without foreign expansion.

(ii) Skill structure. A number of studies corroborates that a process of skill-upgrading is prevalent in Germany as in most of the other countries. Geishecker and Görg (2008a) document that German manufacturing experienced a tremendous increase in outsourcing activities in the 1990s. Allowing for individual fixed effects, they find evidence for low-skilled workers being the losers in globalized production in that they experienced a reduction in real wages. Highskilled workers, on the other hand, benefited from extended trade relations through increased wages. These results are in line with the findings of Geishecker (2004), who states that with nearly stable relative wages in the 1990s, the decline in the relative demand for low-skilled labor can be explained to a considerable extent by international outsourcing. In contrast to this, The work by Marin (Marin 2004; Lorentowicz, Marin and Raubold 2005) provides interesting counterexamples to the mainstream view of a skill-upgrading in high-income countries. Building on the work of Feenstra and Hanson (1996a, 1996b) she provides evidence for relocation not of low-skilled but of high-skilled jobs from Germany and Austria to Eastern Europe through outsourcing. According to Lorentowicz, Marin and Raubold (2005), higher skill premia emerged therefore in Poland, whereas Austria actually experienced a squeeze of the skill premium as a result of this outsourcing activity. ${ }^{26}$

(iii) Employment volatility. Some recent studies analyze the impact of offshoring on the workers' risk of losing their jobs. The study by Buch and Lipponer (2010) does not suggest a higher labor market uncertainty for workers in multinational firms. Using linked employeremployee data, Becker and Muendler (2008) find that the probability of job separation is lower in companies which are expanding abroad. Exploiting data from the IAB Employment Sample, Bachmann and Braun (2008) also find no significant effect of offshoring on job stability in the manufacturing sector, but increased job stability in the service sector. In contrast, the findings of Pfaffermayr et al. (2007) and Geishecker (2008) lend support to the hypothesis that international outsourcing lowers individual employment security, at least in the manufacturing sector.

\footnotetext{
${ }^{26}$ A skill upgrading in the EU accession countries is confirmed in Bruno et al. (2004) and Skuratowicz (2005).
} 


\section{Where further research is needed}

Our review reveals that in recent years path-breaking theoretical innovations have been made in the fields of trade, location and the multinational firm, and that a sizable empirical literature has started scrutinizing the labor market effects of trade and FDI. However, many issues are not or only partially explored and the pre-existing works have a number of limitations.

(1) Key hypotheses and research questions are empirically unexplored. The new theories of trade, location and the multinational firm open up an important empirical research agenda that is largely unexplored.

First, the empirical labor market studies have mostly looked at the effects of offshoring activities on the skill differential and the skill structure of employment. Although this is an important aspect, a more in-depth analysis is required that goes beyond the dichotomy of skilled and unskilled labor. Looking at the characteristic tasks carried out by workers opens up a new perspective at the interface between international trade and labor economics. Moreover, as highlighted by Feenstra (2010) among others, it is important to learn more about the structure of offshoring costs.

Second, recent studies addressing the slicing-the-value-chain phenomenon derive a productivity effect such that all skill groups might gain from the corresponding relocation of economic activity. Increasing output per worker is implied by the literature on firm heterogeneity too. However, the productivity effects associated with outsourcing/offshoring or firm selection processes in response to trade liberalization are empirically (largely) unexplored so far.

Third, if countries' technologies and factor supplies are similar, the existence of technological externalities and of offshoring costs leads to the result that larger countries specialize on tasks that are most costly to offshore while small countries perform tasks that can be offshored at low or modest costs. This 'country size effect' identified in the study by Grossman and RossiHansberg (2009) has not yet been looked at in the empirical literature.

Finally, the literature combining firm heterogeneity with imperfect labor markets implies strong within-group wage and employment inequalities. This effect has not been put under close scrutiny in the empirical literature so far.

(2) Unresolved issues and controversies. Pre-existing empirical research exhibits important unresolved issues and controversies. 
First, the existing empirical work shows that, overall, production relocations within multinational firms seem to have only limited effects on the labor market and that the same holds true for the effects of service offshoring and outsourcing. However, the work pertaining to Germany does not provide unambiguous answers to the labor market consequences of trade and FDI although most studies seem to agree that there are only limited (if any) negative effects on employment and the wage gap between skill groups. This observation has led some observers (e.g. the 'Wissenschaftlicher Beirat beim Bundesministerium für Wirtschaft und Technologie' 2006) to conclude that the public debate overestimates the risks und underestimates the opportunities associated with the globalisation of markets. However, there is still considerable controversy. Whereas some studies find more significant effects (e.g. Sinn 2005) others challenge the conventional wisdom on skill group effects (e.g. Marin and co-authors). Moreover, as highlighted in our review of recent theoretical advances, the empirical literature has ignored a number of important channels and mechanisms that are important in this context. These issues merit reconsideration.

Second, offshoring and outsourcing raise a further issue, the volatility of employment. The magnitude of this volatility is not clear yet. By now, the empirical literature has largely neglected recent works on firm heterogeneity and labor markets which provide explicit explanations for a churning in the labor market.

(3) Unexplored theoretical issues. Recent advances in the theories of trade, location and the multinational firm have left out important theoretical issues.

First, the labor market implications of recent theories of trade and FDI are not fully understood, yet. This concerns the complex integration and sourcing strategies of business firms.

Second, even though the workings of labor markets play a crucial role in recent agglomeration theories, the labor market effects and implications themselves have not been studied.

Third, important research gaps exist at the interface between new theories of trade, location and the multinational firm. Agglomeration effects merit further consideration, not only within the realm of the theory of the multinational firm but also with respect to firm heterogeneity.

Advances along these lines, in particular the provision of structural models, are necessary for further progress from an empirical point of view.

(4) Cross-border investigations lacking. Clearly, the fall of the Iron Curtain and the subsequent trade liberalization had effects not only on Western European labor markets, but also on those in the transition countries. The bulk of studies focuses on the effects in Western 
countries. However, the employees in the Central and Eastern European countries were subject to even deeper changes during the first years on their way from planned to market economy. Not only were the formerly dependable delivery areas of the COMECON lost, but also many state-owned enterprises were not ready for competition when foreign direct investment entered the country. As Egger and Egger (2002: 83) critically note "... the theoretical analysis and empirical assessment ... of international outsourcing is rather new and at least concerning its implications for developing countries it seems to be still in its infancy." ${ }^{27}$ Furthermore, there is little research on the main causes for bringing production activities back to the domestic country. This gap can be addressed by conducting empirical research on both sides of the respective borders.

(5) Spatial aspects not yet fully taken into account in empirical work. It appears fair to claim that, despite a small number of exceptions, spatial aspects have not yet been given enough attention in previous research.

First, most of the existing studies address the FDI of German companies world-wide. Focusing on specific countries or regions is rather an exception. Because of idiosyncratic characteristics of different regions a focus on a specific case promises further and sharper insights. The case of Germany and the CEE countries - in particular the Czech Republic - appears particularly fruitful from this point of view. The economy of the Czech Republic as the target of investment is especially interesting, since this country is the one with the highest number of German direct and indirect investment in Eastern Europe (Deutsche Bundesbank 2010).

Second, the more detailed spatial aspects of offshoring are completely disregarded in current research. Despite a mighty trend towards the development of an own sub-discipline of spatial econometrics and despite a general renewal of interest in regional questions, the literature focuses mainly on why firms locate in foreign countries but not where they locate in those countries (Pusterla and Resmini 2007). An exception is the study of Brandmeier (2005) based on a (small) survey of East Bavarian establishments. The results support the view that distance (still) matters for launching economic relations with CEE countries (Brandmeier 2005). For the specific case of Germany and these countries and the Czech Republic in particular, there are a number of important unresolved questions:

(i) Is German FDI in the Czech Republic still concentrated in large cities and along the border with Germany and Austria as some evidence for the 1990s suggests (Rehner 1998)? Buch et al.

\footnotetext{
${ }^{27}$ Pusterla and Resmini (2007: 839) reinforce this view: "The Central and Eastern Europe region has been only marginally considered in the empirical literature on firm location choice."
} 
(2005) confirm with respect to proximity to the German borders that the number of affiliates of German firms is larger in countries close to Germany, whereas the size of the affiliates increases with distance.

(ii) Is there a process of increasing decentralization of employment and production in the Czech Republic similar to the one observed in the U.S.-Mexican case?

(iii) Quite naturally, border regions have a special position in countries and they should therefore also have a special role in the integration process. In the economic sense a border constitutes an institution which imposes (sometimes prohibitive) transaction costs on the exchange of goods and services between regions or countries (e.g. Büttner and Rincke 2007). Integration reduces these impediments, in particular between border regions, but mental and language barriers might still play an important role, putting these regions in a particular economic situation (Houtum 1999). Nevertheless, one would expect that "[f]rontier regions, such as border areas and port cities, have relatively low-cost access to foreign markets and hence are natural production sites" (Hanson 1996: 942). Hence the labor market effects of economic integration can be expected to be particularly strong in border regions.

(iv) Do we observe agglomeration effects, for instance a concentration of FDI investment in big cities of the target country? If so, what are the causes then?

(6) Lack of appropriate micro-data sets hinders progress. Arguably, the single most important factor which has imposed limitations on the research is the lack of appropriate microdata sets. This has been highlighted by Helpman (2006) who, in his influential survey argues that, "... hypotheses that require detailed firm-level data about trade in different types of products, such as intermediate inputs versus final goods, and whether this trade takes place within the boundary of the firm or at arm's-length, cannot be examined. The theoretical models point out, however, what additional data need to be collected in order to improve the empirical analysis." This data problem has several aspects.

First, because of the lack of micro-data, the bulk of existing empirical research is based on aggregate data (e.g. the studies on the employment effects of offshoring conducted by Feenstra and Hanson (1996b; 1999), Egger and Egger (2003; 2005) and Hsie and Woo (2005)). Yet, investigations with aggregate or industry-level data may suffer from aggregation and endogeneity bias and contain, if at all, rather sketchy control variables for skills and education (Geishecker 2008). 
Second, certain specific characteristics simply cannot be studied with industry level data. With regard to international outsourcing, for example Klodt (2007) ascertains the lack of data containing information on the share of intermediate trade concerning deliveries within a multinational concern (between parent company and affiliate) or on the role of trade relations with independent suppliers.

Third, the lack of adequate data sets limits the applicability of econometric methods which requires control groups (of workers or firms).

Finally, to be sure, micro-data have been used in a number of recent studies (see in particular our discussion of the 'Studies pertaining to Germany'). However, data constraint imposed two types of limitations on those studies as well.

(i) Although the empirical studies quoted in that section are comprehensive in the sense that they do not make restrictions concerning the location in the world where the investment is undertaken, the data used is selective with respect to the characteristics of the enterprises and/or the investment projects included. The MIDI database includes only those investment projects where the foreign affiliates of German mothers fulfil at least one of two criteria. The first one requires a balance sheet of more than 5 Mio $€$ and at least a ten percent ownership share of the German firm. The other one requires a balance sheet of 0.5 Mio $€$ and at least a fifty percent ownership share (Becker and Muendler 2010). Moreover, the reported thresholds have been changed several times in recent years. At present, only firms are counted which have a foreign subsidiary which represents a balance sheet total of at least 3 million $€$. This might appear not to be very restrictive. However, taking into account that there are many small firms, it is not clear, what this bias in favour of large firms exactly implies. The selectivity of the MIDI data base is tentatively shown by a comparison with the 'Going International survey' (Buch, Schnitzer et al. 2007). ${ }^{28}$

(ii) The fusion of different data sources, though clearly a valid strategy, typically works only imperfectly. Many theoretical meaningful variables are not available even when files are joined together. This issue clearly highlights the usefulness of a special survey. Such a survey can also avoid the mentioned selectivity problem, since it can be representative for the whole population.

These problems associated with pre-existing data constraints point to the need of a carefully planned comprehensive micro-database to be used to analyze the labor market effects of trade and foreign investment.

\footnotetext{
${ }^{28}$ The response rate of this postal survey was only 8\%, however (Buch, Schnitzer et al. 2007: 36).
} 


\section{Conclusion}

This paper has reviewed theoretical advances in the fields of trade, location and the multinational firm which allow a fresh look at the relationship between trade, foreign direct investment and labor markets. We have also surveyed the existing empirical work with particular focus on developments in Germany. Taking stock we have found that many issues are not or only partially explored and the pre-existing theoretical and empirical works have a number of limitations. In identifying these gaps we have highlighted promising avenues for future research.

\section{References}

Acemoglu, D. (2002): Technical change, inequality, and the labor market, Journal of Economic Literature, 40(1), $7-72$.

Acemoglu D. and D. Autor (2010): Skills, Tasks and Technologies: Implications for Employment and Earnings, in: O. Ashenfelter and D. E. Card (eds.) Handbook of Labor Economics, Vol. 4, Elsevier B.V., Amsterdam, forthcoming.

Airola, J. and C. Juhn (2005): Wage Inequality in Post-Reform Mexico, IZA Discussion Paper 1525.

Alfaro, L. and A. Charlton. (2009): Intra-industry Foreign Direct Investment, American Economic Review, 99(5), 2096-2119.

Amiti, M. and S.-J. Wei (2005): Fear of Service Outsourcing: Is it Justified?, Economic Policy, 20(42), 308-347.

Amiti, M. and S.-J. Wei (2006): Service Offshoring, Productivity and Employment: Evidence from the US, CEPR Discussion Paper 5475.

Antonczyk, D., B. Fitzenberger and U. Leuschner (2009): Can a Task-Based Approach Explain the Recent Changes in the German Wage Structure?, Jahrbücher für Nationalökonomie und Statistik, 229(2-3), 214238.

Antras, P. (2003): Firms, contracts, and trade structure, Quarterly Journal of Economics, 118(4), 1375-1418.

Antras, P. and E. Helpman (2004): Global Sourcing, Journal of Political Economy 112(3): 552-580.

Antras, P. and E. Helpman (2008): Contractual frictions and global sourcing, in: E. Helpman, D. Marin and T. Verdier (eds.), The Organization of Firms in a Global Economy, Harvard University Press, Cambridge, 944.

Arndt, S.W. and H. Kierzkowski (2001): Fragmentation: New Production Patterns in the World Economy, Oxford University Press, Oxford.

Autor, D. H. and D. Dorn (2009): Inequality and Specialization: The Growth of Low-Skill Service Jobs in the United States, IZA Discussion Paper 4290.

Autor, D., F. Levy and R. Murnane, (2003): The Skill Content of Recent Technological Change: An Empirical Investigation, Quarterly Journal of Economics, 118(4), 1279-1333.

Autor, D., L. Katz and M. Kearny (2006): The Polarization of the U.S. Labor Market, American Economic Review, 96(2), 189-194.

Bachmann, R. and S. Braun (2008): The Impact of International Outsourcing on Labour Market Dynamics in Germany, SFB Discussion Paper 2008-020.

Baldwin, R., R. Forslid, P. Martin, G. Ottaviano, F. Robert-Nicoud (2003): Economic geography and public policy, Princeton University Press, Princeton. 
Baldwin, R. (2006): Globalization: the Great Unbundling(s), paper for the Finnish Prime Minister's Office, Economic Council of Finland as part of the EU Presidency, Helsinki, 20 September 2006.

Barba Navaretti, G. and A.J. Venables (2004): Multinational Firms in the World Economy, Princeton University Press, Princeton.

Barba Navaretti, G. and D. Castellani (2008): Do Italian Firms Improve Their Performance at Home by Investing Abroad?, in: S. Brakman, H. Garretsen (eds.): Foreign Direct Investment and the Multinational Enterprise, MIT Press, Cambridge, 199-224.

Becker, S.O. and M.-A. Muendler (2010): Margins of multinational labor substitution, Discussion Paper, American Economic Review, forthcoming.

Becker, S.O., K. Ekholm, R. Jäckle, and M.-A. Muendler (2005): Location choice and employment decisions: a comparison of German and Swedish multinationals, Review of World Economics, 141(4), 693-731.

Becker, S.O. and M.-A. Muendler (2008): The Effect of FDI on Job Security, B.E. Journal of Economic Analysis \& Policy: Advances, 8(1), Article 8.

Bernard, A.B. and J. B. Jensen (1995): Exports, Jobs and Wages in U.S. Manufacturing, 1976-87, Brookings Papers on Economic Activity: Microeconomics, 67-119.

Bernard, A.B., J. Eaton, J.B. Jensen and S.S. Kortum (2003): Plants and Productivity in International Trade, American Economic Review, 93(4), 1268-1290.

Bernard, A.B., J.B. Jensen, S. Redding and P. Schott (2007): Firms in International Trade, Journal of Economic Perspectives, 21(3), 105-130.

Bernard, A.B. and J.B. Jensen (1999): Exceptional Exporter Performance: Cause, Effect, or Both?", Journal of International Economics, 47(1), 1-25.

Bernard, A.B. and J.B. Jensen (2004): Why Some Firms Export, Review of Economics and Statistics, 86(2), 561569.

Bernard, A.B., J.B. Jensen, P.K. Schott (2009): Importers, Exporters and Multinationals: A Portrait of Firms in the U.S. that Trade Goods, in Producer dynamics: New Evidence from Micro Data, 2009, T. Dunne, J.B. Jensen and P.K. Schott, University of Chicago Press.

Bernard, A.B., S.J. Redding and P.K. Schott (2006): Survival of the Best Fit: Exposure to Low Wage Countries and The (Uneven) Growth of US Manufacturing Plants, Journal of International Economics, 68(1), 219-237.

Bernard, A.B., S.J. Redding and P.K. Schott (2007): Comparative Advantage and Heterogeneous Firms, Review of Economic Studies, 74(1), 31-66.

Bhagwati, J.A. and A.S. Blinder (2009): Offshoring of American Jobs. What Response from U.S. Economic Policy? The MIT Press, Cambridge, Mass.

Bhagwati, J., A. Panagariya and T.N. Srinivasan (2004): The muddles over outsourcing. Journal of Economic Perspectives, 18(4), 93-114.

Blinder, A. S. (2006): Offshoring: the Next Industrial Revolution? Foreign Affairs, 85(2), 113-128.

Braconier, H. and K. Ekholm, (2000): Swedish multinationals and competition from high and low-wage locations, Review of International Economics, 8(3), 448-461.

Brandmeier, M. (2005): Die ökonomische Integration der mittelosteuropäischen Länder - Außenhandel, Outsourcing, Direktinvestitionen und Unternehmenskooperationen, Dissertation, Josef Eul, Lohmar-Köln.

Brülhart, M., (2010): The Spatial Effects of Trade Openness: A Survey, mimeo, Lausanne.

Brülhart, M., M. Crozet and P. Koenig (2004): Enlargement and the EU Periphery: The Impact of Changing Market Potential, World Economy, 27(6), 853-875.

Bruno, G.S.F., R. Crinò and A.M. Falzoni (2004): Foreign Direct Investment, Wage Inequality and Skilled Labor in EU Accession Countries, Centre of Research on Innovation and Internationalization, Working Paper 154, University Bocconi.

Buch, C. and A. Lipponer (2010): Volatile Multinationals? Evidence from the Labor Demand of German Firms, Labour Economics, 17(2), 345-353.

Buch, C., J. Kleinert and F. Toubal (2003): Determinants of German FDI: New Evidence from Micro-Data, Discussion Paper 09/03, Economic Research Centre of the Deutsche Bundesbank. 
Buch, C., J. Kleinert, A. Lipponer and F. Toubal (2005): Determinants and Effects of Foreign Direct Investment: Evidence from German Firm-Level Data, Economic Policy, 20(41), 52-110.

Buch, C.M., M. Schnitzer, C. Arndt, I. Kesternich, A. Mattes, C. Mugele and H. Strotmann (2007): Analyse der Beweggründe, der Ursachen und der Auswirkungen des so genannten Offshoring auf Arbeitsplätze und Wirtschaftsstruktur in Deutschland, IAW, Tübingen.

Büttner, T. and J. Rincke (2007): Labor Market Effects of Economic Integration - the Impact of Unification in German Border Regions, German Economic Review, 8(4), 536-560.

Chiquiar, D. (2008): Globalization, Regional Wage Differentials and the Stolper-Samuelson Theorem: Evidence from Mexico, Journal of International Economics, 74(1), 70-93.

Cline, W.R. (1997): Trade and Income Distribution, Institute for International Economics, Washington, DC.

Combes, P.-P., T. Mayer and J.F. Thisse (2008): Economic geography: the integration of regions and nations, Princeton University Press, Princeton.

Combes, P.-P., G. Duranton, L. Gobillon, and S. Roux (2009): Estimating agglomeration economies with history, geology and worker effects, CEPR Working paper 6278.

Crinò, R. (2008): Service offshoring and productivity in Western Europe, Economics Bulletin, 6(35), 1-8.

Crinò, R. (2009a): Offshoring, Multinationals and Labour Market: A Review Of The Empirical Literature, Journal of Economic Surveys, 23(2), 197-249.

Crinò, R. (2009b): Service offshoring and white-collar employment, Review of Economic Studies, forthcoming.

Davis, D.R.and J. Harrigan (2010): Good Jobs, Bad Jobs, and Trade Liberalization, Columbia University, Department of Economics, mimeo.

Deardorf A.V. (2001a): Fragmentation in Simple Trade Models, North American Journal of Economics and Finance, 12(2), 121-137.

Deardorf A.V. (2001b): Fragmentation across cones, in: S.W. Arndt and H. Kierzkowski (eds.), Fragmentation: New Production Patterns in the World Economy, Oxford University Press, Oxford.

Deutsche Bundesbank (2007): Bestandserhebung über Direktinvestitionen, Statistische Sonderveröffentlichung 10, Deutsche Bundesbank, Frankfurt.

Deutsche Bundesbank (2010): Bestandserhebung über Direktinvestitionen, Statistische Sonderveröffentlichung 10, Deutsche Bundesbank, Frankfurt.

DIHK (2008): Investitionen im Ausland - Ergebnisse einer DIHK-Umfrage bei den Industrie- und Handelskammern, Deutscher Industrie- und Handelskammertag, Berlin.

Dixit, A.K. and J.E. Stiglitz (1977): Monopolistic Competition and Optimum Product Diversity, American Economic Review, 67(3), 297-308.

Dornbusch, R., S. Fischer and P.A. Samuelson (1980): Heckscher-Ohlin Trade Theory with a Continuum of Goods, Quarterly Journal of Economics, 95(2), 203-224.

Dunning, J.H. (1977): Trade, Location of Economic Activity and the MNE: A Search for an Eclectic Approach, in: B. Ohlin, P.O. Hasselborn, P.A. Wijkman (eds.): The International Allocation of Economic Activity, Macmillan, London, 395-431.

Dunning, J.H. (1981): International Production and the Multinational Enterprise, George Allen and Unwin, London.

Duranton, G and D. Puga (2004): Micro-foundations of urban agglomeration economies, in: J.V. Henderson and J.F. Thisse (eds.), Handbook of Regional and Urban Economics, Vol. 4, Elsevier B.V., Amsterdam, 2063-2117.

Dustmann, C., J. Ludsteck and U. Schönberg (2009): Revisiting the German Wage Structure, Quarterly Journal of Economics, MIT Press, 124(2), 843-881.

Eckel, C. and H. Egger (2009): Wage bargaining and multinational firms, Journal of International Economics, 77(2), 206-214.

Eckel, C. and J.P. Neary (2010): Multi-Product Firms and Flexible Manufacturing in the Global Economy, Review of Economic Studies, 77(1), 188-217.

Egger, H. and Falkinger, J. (2003): The distributional effects of international outsourcing in a $2 \times 2$ production model, North American Journal of Economics and Finance, 14(2), 189-206. 
Egger, H. and U. Kreickemeier (2008): International fragmentation: boon or bane for domestic employment?, European Economic Review, 52(1), 116-132.

Egger, H. and U. Kreickemeier (2009): Firm Heterogeneity and the Labor Market of Trade Liberalization, International Economic Review, 50(1), 187-216.

Egger, H. and U. Kreickemeier (2007): Globalisierung, Firmenselektion und Arbeitsmärkte, in: W. Franz, J. Ramser and M. Stadler (eds.), Dynamik internationaler Märkte, Mohr Siebeck, Tübingen, 123-142.

Egger, H. and P. Egger (2002): How International Outsourcing Drives Up Wages in Eastern Europe?, Weltwirtschaftliches Archiv, 138(1), 83-96.

Egger, H. and P. Egger (2003): Outsourcing and Skill-specific Employment in a Small Economy: Austria and the Fall of the Iron Curtain, Oxford Economic Papers, 55(4), 625-643.

Egger, H. and P. Egger (2005): The Determinants of EU Processing Trade, World Economy, 28(2), 147-168.

Ekholm, K, R. Forslid and J.R. Markusen (2004): Export-Platform Foreign Direct Investment, University of Colorado, mimeo.

Ellison, G., E.L. Glaeser and W.R. Kerr (2010): What Causes Industry Agglomeration? Evidence from Coagglomeration Patterns, American Economic Review, 100(3), 1195-1213.

Eriksson, T. and M. Pytlikova (2009): Foreign Ownership Wage Premia in Emerging Economies: Evidence from Czech Republic, Working Papers 09-14, University of Aarhus, Aarhus School of Business, Department of Economics.

Feenstra, R.C. (1998): Integration of trade and disintegration of production in the global economy. Journal of Economic Perspectives, 12(4), 31-50.

Feenstra, R.C. (2010): Offshoring in the Global Economy, Microeconomic Structure and Macroeconomic Implications, MIT Press, Cambridge.

Feenstra, R.C. and H. Ma (2008): Optimal Choice of Product Scope for Multiproduct Firms under Monopolistic Competition, in: E. Helpman, D. Marin and T. Verdier (eds.), The Organization of Firms in a Global Economy, Harvard University Press, Cambridge, 173-199.

Feenstra, R.C. (2004): Advanced International Trade: Theory and Evidence, Princeton University Press, Princeton.

Feenstra, R.C. and G. Hanson (1996a): Foreign Investment, Outsourcing and Relative Wages, in: R.C. Feenstra, G. Grossman, D. Irwin, (eds.), Political Economy of Trade Policy: Essays in Honour of Jagdish Bhagwati, MIT Press, Cambridge, 89-127.

Feenstra, R.C. and G. Hanson (1996b): Globalization, Outsourcing, and Wage Inequality, American Economic Review, 86(2), 240-245.

Feenstra, R.C. and G. Hanson (1997): Foreign Direct Investment and Relative Wages: Evidence from Mexico's Maquiladoras, Journal of International Economics, 42(3-4), 371-393.

Feenstra, R.C. and G. Hanson (1999): The Impact of Outsourcing and High-Technology Capital on Wages: Estimates for the United States, 1979-1990, Quarterly Journal of Economics, 114(3), 907-940.

Feenstra, R.C. and G. Hanson (2003): Global Production Sharing and Rising Inequality: A Survey of Trade and Wages, in: E. Choi, J. Harrigan (eds.), Handbook of International Trade, Blackwell Publishing, Oxford, 146-185.

Felbermayr, G. and J. Prat (2010): Product Market Regulation, Firm Selection and Unemployment, Journal of the European Economic Association, forthcoming

Fujita, M. and T. Mori (2005): Transport development and the evolution of economic geography, Portuguese Economic Journal, 4(2), 129-156.

Fujita, M., P.R. Krugman and A.J. Venables (1999): The spatial economy. Cities, regions, and international trade, MIT Press, Cambridge.

Galuščák, K. and D. Münich (2005): Regional Wage Adjustments and Unemployment: Estimating the TimeVarying Wage Curve, Czech Journal of Economics and Finance, 55(2), 68-82.

Geishecker, I. (2004): Outsourcing and the Demand for Low-skilled Labour: Exemplary Evidence from German Manufacturing Industries, in: D. Meulders, R. Plasman, F. Rycx, (eds.), Minimum Wages, Low Pay and Unemployment, Palgrave Macmillan, New York, 176-194. 
Geishecker, I. (2008): The Impact of International Outsourcing on Individual Employment Security: A MicroLevel Analysis, Labour Economics, 15(3), 291-314.

Geishecker, I. and H. Görg (2008a): Winners and Losers: A Micro-Level Analysis of International Outsourcing and Wages, Canadian Journal of Economics, 41(1), 243-270.

Geishecker, I. and H. Görg (2008b): Services Offshoring and Wages: Evidence from Micro Data, IZA Discussion Paper 3593.

Glaeser E.L. and J.D. Gottlieb (2010), The Wealth of Cities: Agglomeration Economies and Spatial Equilibrium in the United States, Journal of Economic Literature, 47(4), 983-1028.

Goldberg, P.K. and N. Pavcnik (2007): Distributional Effects of Globalization in Developing Countries, Journal of Economic Literature, 45(1), 39-82.

Goos, M. and A. Manning (2007): Lousy and Lovely Jobs: The Rising Polarization of Work in Britain, Review of Economics and Statistics, 89(1), 118-133.

Goos, M., A. Manning and A. Salomons (2009): Job Polarization in Europe, American Economic Review, 99(2), 58-63.

Görg, H., D. Greenaway and R. Kneller, (2008): The Economic Impact of Offshoring, GEP Research Report.

Grossman S.J. and O.D. Hart (1986): The Costs and Benefits of Ownership: A Theory of Vertical and Lateral Integration, Journal of Political Economy, 94(4), 691-719.

Grossman, G.M. and E. Rossi-Hansberg (2010): Task Trade between Similar Countries, Quarterly Journal of Economics, forthcoming.

Grossman, G.M. and E. Rossi-Hansberg (2006): The Rise of Offshoring: It's Not Wine for Cloth Anymore, in: Federal Reserve Bank of Kansas City (ed.), The New Economic Geography: Effects and Policy Implications, Jackson Hole, 59-102.

Grossman, G.M. and E. Rossi-Hansberg (2008): Trading Tasks: A Simple Theory of Offshoring, American Economic Review, 98(5), 1978-1997.

Grossman, G.M., E. Helpman and A. Szeidl (2006): Optimal integration strategies for the multinational firm, Journal of International Economics, 70, 216-238.

Handelsblatt (2005): Siemens engagiert Buchhalter in Prag - Deutsche Firmen verlagern Bürojobs nach Tschechien, 19.09.05.

Hanson, G. (1996): Economic Integration, Intraindustry Trade, and Frontier Regions, European Economic Review, 40(3-5), 941-949.

Hanson, G. (1998): Regional Adjustment to Trade Liberalization, Regional Science and Urban Economics, 28(4), 419-444.

Hanson, G. (2001): U.S.-Mexico Integration and Regional Economies: Evidence from Border-City Pairs, Journal of Urban Economics, 50(2), 259-287.

Harkness, J., F. van de Vijver and P. Mohler (eds.) (2003): Cross-Cultural Survey Methods, Wiley-Interscience, Hoboken/New Jersey.

Head K. and T. Mayer (2004): Market Potential and the Location of Japanese Investment in the European Union, Review of Economics and Statistics, 86(4), 959-972.

Head, K. and J. Ries (2002): Offshore Production and Skill Upgrading by Japanese Manufacturing Firms, Journal of International Economics, 58(1), 81-105.

Heckman, J., R. LaLonde and J. Smith (1999): The Economics and Econometrics of Active Labor Market Programs, in: O. Ashenfelter and D. Card (eds.), Handbook of Labor Economics, Vol. 3A, Elsevier B.V., Amsterdam, 1865-2097.

Helpman, E. (1998): The size of regions, in: D. Pines, E. Sadka and I. Zilcha (eds.), Topics in Public Economics. Theoretical Analysis, Cambridge University Press, 33-54.

Helpman, E. and O. Itskhoki (2010), Labor Market Rigidities, Trade and Unemployment, Review of Economic Studies, 77 (3), 1100-1137

Helpman, E., O. Itskhoki and S. Redding (2010a), Inequality and Unemployment in a Global Economy, Econometrica, 78 (4), 1239-1283 
Helpman, E., O. Itskhoki and S. Redding (2010b), Trade and Labor Market Outcomes, Frisch Lecture,

Econometric Society World Congress, paper prepared for the conference monographs, forthcoming, 2011

Helpman, E. and P. Krugman (1985): Market Structure and Foreign Trade: Increasing Returns, Imperfect Competition, and the International Economy, MIT Press, Cambridge.

Helpman, E. (2006): Trade, FDI, and the Organization of Firms, Journal of Economic Literature, 44(3), 589-630.

Helpman, E., D. Marin and T. Verdier (2008): The Organization of Firms in a Global Economy, Harvard University Press, Cambridge.

Hijzen, A., H. Görg and R. Hine (2005): International Outsourcing and the Skill Structure of Labor Demand in the United Kingdom, Economic Journal, 115(506), 860-878.

Houtum, H. van (1999): What is the Influence of Borders on Economic Internationalisation?, in: P. de Gijsel, M. Janssen, H.-J. Wenzel and M. Woltering (eds.), Understanding European Cross-Border Labour Markets, Metropolis-Verlag, Marburg, 107-141.

Hsieh, C.T. and K.T. Woo (2005): The Impact of Outsourcing to China on Hong Kong's Labor Market, American Economic Review, 95(5), 1673-1687.

Hummels, D., J. Ishii and K.-M. Yi (2001): The Nature and Growth of Vertical Specialization in World Trade, Journal of International Economics, 54(1), 75-96.

Hummels, D., D. Rapoport, and K.M. Yi (1998): Vertical specialization and the changing nature of world trade. Economic Policy Review, Federal Reserve Bank of New York, 79-99.

Janda, K. and D. Münich (2004): The Intra-Industry Trade of the Czech Republic in the Economic Transition, Emerging Markets Finance and Trade, 40(2), 27-50.

Javorcik, B.S. (2004): Does Foreign Direct Investment Increase the Productivity of Domestic Firms? In Search of Spillovers Through Backward Linkages, American Economic Review, 94(3), 605-627.

Jensen, B.J. and L. Kletzer (2005) Tradable services: understanding the scope and impact of services offshoring, in: L. Brainard and S.M. Collins (eds.), Offshoring White-Collar Work - The Issues and the Implications, Brookings Trade Forum, Washington, D.C., 73-133.

Jones R.W. (1965): The Structure of Simple General Equilibrium Models, Journal of Political Economy, 73(6), 557-572.

Jones R.W. (2000): Globalization and the Theory of Input Trade, MIT Press, Cambridge.

Jones R.W. and H. Kierzkowski (1990): The role of services in production and international trade: a theoretical framework, in: R.W. Jones and A.O. Krueger (eds.), The Political Economy of International Trade, Basil Blackwell, Oxford.

Jost, T. and H. Rottmann (2004): Umfang und Motive deutscher Direktinvestitionen in den Industrieländern, List Forum für Wirtschafts- und Finanzpolitik, 33(2), 153-166.

Jurajda, Š. and D. Münich (2003): Understanding Long-Term Unemployment in the Czech Republic, Czech Journal of Economics and Finance, 53(1), 11-30.

Klodt, H. (2007): Offshoring und Outsourcing in der deutschen Automobilindustrie, List Forum für Wirtschaftsund Finanzpolitik, 33(2), 129-140.

Klodt, H. and B. Christensen (2007): Home Market Effects of Foreign Direct Investment: The Case of Germany, Aussenwirtschaft, 62(1), 63-76.

Kohler, W. (2004a): Aspects of International Fragmentation, Review of International Economics, 12(5), 793-816.

Kohler, W. (2004b): International outsourcing and Factor Prices with Multistage Production, Economic Journal, 114(494) 166-185.

Kohler, W. (2007): The Bazaar Effect, Unbundling of Comparative Advantage, and Migration, in: W. Franz, H.J. Ramser and M. Stadler (eds.), Dynamik internationaler Märkte, Mohr-Siebeck, Tübingen, 147-182.

Kohler, W. (2008): Offshoring: Why do Stories differ?, CESifo Working Paper 2231.

Konings J. and A. Murphy (2006): Do Multinational Enterprises Relocate Employment to Low-Wage Regions? Evidence from European Multinationals, Review of World Economics, 142(2), 267-286.

Kosová, R. (2006): Do Foreign Firms Crowd Out Domestic Firms? Evidence from the Czech Republic, Working Paper 0006, School of Business and Public Management, George Washington University. 
Kosová, R. (2010): Do Foreign Firms Crowd Out Domestic Firms? Evidence from the Czech Republic, The Review of Economics and Statistics, 92(4), 861-881.

Krugman, P. (1979): Increasing Returns, Monopolistic Competition, and International Trade, Journal of International Economics, 9(4), 469-479.

Krugman, P. (1991a): Increasing returns and economic geography, Journal of Political Economy, 99(3), $483-499$.

Krugman, P. (1991b): Geography and trade, MIT Press, Cambridge.

Krugman, P. (1994): Past and Prospective Causes of High Unemploymant, in: Reducing Unemployment: Current Issues and Policy Options. A Symposium Sponsored by The Federal Reserve Bank of Kansas City, Jackson Hole, Wyoming, 49-98.

Krugman, P. (2008): Trade and wages, reconsidered, Brookings Papers on Economic Activity Conference Draft , 103-154.

Krugman P. and A. Venables (1995): Globalization and the inequality of nations, Quarterly Journal of Economics, 110(4), 857-880.

Krugman, P. (1980): Scale Economies, Product Differentiation, and the Pattern of Trade, American Economic Review, 70(5), 950-959.

Krugman, P. (1991): Increasing Returns and Economic Geography, Journal of Political Economy, 99(3), 483-499.

Krugman, P. (1994): Does Third World Growth Hurt First World Prosperity?, Harvard Business Review, 72 (JulyAugust), 113-121.

Krugman, P. (1995): Growing World Trade: Causes and Consequences, Brookings Papers on Economic Activity, Economic Studies Program, Brookings Institution, 26(1), 327-377.

Krugman, P. and L.R. Elizondo (1996): Trade Policy and the Third World Metropolis, Journal of Development Economics, 49(1), 137-150.

Leamer, E.E. (1998): In Search of Stolper-Samuelson Linkages between International Trade and Lower Wages. in: S.M. Collins (ed.), Imports, Exports, and the American Worker, Brookings Institution Press, Washington D.C., 141-203.

Leamer, E.E. (2000): What's the Use of Factor Contents?, Journal of International Economics, 50(1), 17-49.

Leamer (2007): A Flat World, a Level Playing Field, a Small World After All, or None of the Above? A Review of Thomas L. Friedman's The World is Flat, Journal of Economic Literature, 45(1), 83-126.

Leamer E.E. and J. Levinsohn (1995): International Trade Theory: The Evidence, in: G. Grossman and K. Rogoff (eds.), Handbook of International Economics, Vol. 3, Elsevier B.V., Amsterdam, 1339-1396.

Levy, F. and R. Murname (2004): The New Division of Labor, Princeton University Press, Princeton.

Lipsey, R. (2006): Measuring the Impacts of FDI in Central and Eastern Europe, NBER Working Paper 12808.

Lorentowicz, A., D. Marin and A. Raubold (2005): Is Human Capital Losing from Outsourcing? Evidence for Austria and Poland, CESifo Working Paper 1616.

Marin, D. (2004): A Nation of Poets and Thinkers: Less so with eastern Enlargement? Austria and Germany, CEPR Discussion Paper 4358.

Marin, D. (2006): A New International Division of Labor in Europe: Outsourcing and Offshoring to Eastern Europe, Journal of the European Economic Association, 4(2-3), 612-622.

Markusen, J.R. (2002): Multinational Firms and the Theory of International Trade, MIT Press, Cambridge.

Mayer, T. and G.I.P. Ottaviano (2007): The Happy Few: the internationalisation of European firms. New facts based on firm-level evidence, Bruegel, Brussels.

Melitz, M.J. and G.I.P. Ottaviano (2008) Market Size, Trade, and Productivity, Review of Economic Studies, 75, 295-316.

Melitz, M.J. (2003): The Impact of Trade on Intra-Industry Reallocations and Aggregate Industry Productivity, Econometrica, 71(6), 1695-1725.

Munch, J.R. (2005) International outsourcing and individual job separations. Working Paper 05-11, Department of Economics, University of Copenhagen. 
Münich, D. and K. Galuščák (2007): Structural and Cyclical Unemployment: What Can We Derive from the Matching Function? Czech Journal of Economic and Finance, 57(3-4), 102-125.

Münich, D. and J. Švejnar (2007): Unemployment in East and West Europe, Labour Economics, 14(4), 681-694.

Münich, D., J. Švejnar and K. Terrell (2005): Is Women's Human Capital Valued More by Markets than by Planners?, Journal of Comparative Economics, 33(2), 278-299.

Münich, D., K. Terrell, K. and J. Švejnar (2005): Returns to Human Capital from the Communist Wage Grid to Transition: Retrospective Evidence from Czech Micro Data, The Review of Economics and Statistics, 87(1), 100-124.

Nocke, V. and S. Yeaple (2006): Globalization and Endogenous Firm Scope, NBER Working Paper 12322, Cambridge, MA.

Nunn and Trefler (2008): The Boundaries of the Multinational Firm, in: E. Helpman, D. Marin and T. Verdier (eds.), The Organization of Firms in a Global Economy, Harvard University Press, Cambridge. 55-83.

OECD (2003): Territorial Reviews; Vienna-Bratislava, Austria/Slovak Republic, Paris.

Pfaffermayr, M., P. Egger and A. Weber (2007): Sectoral Adjustment of Employment to Shifts in Outsourcing and Trade: Evidence from a Dynamic Fixed Effects Multinomial Logit Model, Journal of Applied Econometrics, 22(3), 559-580.

Pflüger, M. (2002): Konfliktfeld Globalisierung. Verteilungs- und Umweltprobleme der weltwirtschaftlichen Integration, Physica-Verlag, Heidelberg

Pflüger, M. (2004a): Trade, Technology and Labour Markets. Empirical Controversies in the Light of the Jones Model, Journal of Economic Integration 19(1), 79-112

Pflüger, M. (2004b): A Simple, Analytically Solvable, Chamberlinian Agglomeration Model, Regional Science and Urban Economics 34, 565-573

Pflüger, M. and T. Tabuchi (2010): Trade and location with land as a productive factor, Regional Science and Urban Economics, 40(6), 481-489

Pusterla, F. and L. Resmini (2007): Where do Foreign Firms Locate in Transition Countries? An Empirical Investigation, Annals of Regional Science, 41(4), 835-856.

Redding, S.J. (2009a): Economic Geography: a Review of the Theoretical and Empirical Literature, CEPR Discussion Paper 7126.

Redding, S.J. (2009b): The Empirics of New Economic Geography, CEPR Discussion Paper 7307.

Redding, S. J., and D.M. Sturm. (2008), The Costs of Remoteness: Evidence from German Division and Reunification, American Economic Review, 98(5), 1766-1797.

Rehner, J. (1998): Direktinvestitionen in der Tschechischen Republik - eine empirische Wirkungsanalyse, in: H.-D. Haas (ed.), Ausgewählte Beiträge zur Direktinvestitionsforschung, Institut für Wirtschaftsgeographie, München, 67-110.

Robertson J., D. Stone, L. Niederwanger, M. Grocki, E. Martin and E. Smith (2005): Offshore Outsourcing of TaxReturn Preparation, CPA Journal, 75(6), 54-57.

Rodrik, D. (1997): Has Globalization Gone Too Far?, Institute for International Economics, Washington.

Römer, C. (2007): Offshoring - Wie viele Jobs gehen ins Ausland? Auslandsinvestitionen, Produktionsverlagerungen und Arbeitsplatzeffekte, IW-Analysen Nr. 26, Deutscher Instituts-Verlag, Köln.

Rosenthal, S.S. and W.C. Strange (2004): Evidence on the nature and sources of agglomeration economies, in: J.V. Henderson and J.F. Thisse (eds.), Handbook of Regional and Urban Economics, Vol. 4. Elsevier B.V., Amsterdam, 2119-2167.

Rubin, D. (1974): Estimating Causal Effects of Treatments in Randomized and Nonrandomized Studies, Journal of Educational Psychology, 66(5), 688-701.

Schank, T., C. Schnabel and J. Wagner (2007): Do Exporters Really Pay Higher Wages? First Evidence from Linked Employer-Employee Data, Journal of International Economics, 72(1), 52-74.

Schank, T., C. Schnabel and J. Wagner (2008): Higher Wages in Exporting Firms: Self-Selection, Export Effect, or Both? First Evidence from German Linked Employer-Employee Data, IZA Discussion Paper 3359. 
Schott, P.K. (2008): The relative sophistication of Chinese exports, Economic Policy, 23(53), 5-49.

Sethupathy, G. (2008) Offshoring, Wages, and Employment: Theory and Evidence, unpublished manuscript, Columbia University.

Shapiro C. and J.E. Stiglitz (1984): Equilibrium Unemployment as a Worker Discipline Device, American Economic Review, 74, 433-444.

Sinn, H.-W. (2005): Die Basar-Ökonomie. Deutschland: Exportweltmeister oder Schlusslicht?, Econ, Berlin.

Skuratowicz, A. (2005): Growing Wage Inequalities in Poland: Could Foreign Investment be Part of the Explanation?, ECFIN Country Focus, 2(5), European Commission, Brussels.

Spitz-Oener, A. (2006): Technical Change, Job Tasks and Rising Educational Demands: Looking Outside the Wage Structure, Journal of Labor Economics, 24(2), 235-270.

Statistisches Bundesamt (2008): 60\% der Unternehmensverlagerungen gehen in die neuen EU-Länder, Pressemitteilung Nr. 046, 07.02.2008.

Statistisches Bundesamt (2009): Verflechtung deutscher Unternehmen mit dem Ausland, Begleitmaterial zur Pressekonferenz am 17. Februar 2009, Berlin.

Stephan, A. (2007): Der Nutzen von Firmendaten für die wirtschaftspolitische Beratung, Vierteljahrshefte zur Wirtschaftsforschung, 76(3), 5-7.

Tabuchi T. (1998): Agglomeration and dispersion: a synthesis of Alonso and Krugman, Journal of Urban Economics, 44(3), 333-351.

Temouri, Y. and L. Driffield (2009): Does German Foreign Direct Investment Lead to Job Losses at Home?, Applied Economics Quarterly, 55(3), 243-263.

Thurm, S. (2004): Tough Shift - Lesson in India: Not Every Job Translates Overseas, New York Times, March 3.

UNCTAD (1998): World Investment Report, Trends and determinants, United Nations, Geneva.

Venables, A. J. (1996): Equilibrium Locations of Vertically Linked Industries Author(s): Source: International Economic Review,37(2), 341-359.

Wagner, J. (2007): Exports and Productivity: A Survey of the Evidence from Firm Level Data, World Economy, $30(1), 60-82$.

Wheeler J.D. and A. Mody (1992): International investment location decisions: the case of U.S. firms, Journal of International Economics, 33(1-2), 57-76.

Wissenschaftlicher Beirat (2006): Der deutsche Arbeitsmarkt in Zeiten globalisierter Märkte, Wissenschaftlicher Beirat beim Bundesministerium für Wirtschaft und Technologie.

Wood, A. (1995): How Trade Hurt Unskilled Workers, Journal of Economic Perspectives, 9(3), 57-80.

Wooldridge, J. M. (2009): Introductory Econometrics, Fourth Edition, Cincinnati.

WTO (1998): Annual Report, World Trade Organization, Geneva.

WTO (2008): World Trade Report, World Trade Organization, Geneva.

Yeaple, S.R. (2003): The Complex Integration Strategies of Multinationals and Cross Country Dependencies in the Structure of Foreign Direct Investment, Journal of International Economics, 60(2), 293-314.

Yeaple, S.R. (2005), A Simple Model of Firm Heterogeneity, International Trade, and Wages, Journal of International Economics, 65(1), 1-20. 